\title{
製造業のサービス化を支援する 実践手法の開発 \\ Development of Pragmatical Methods to Support Manufactures Servicification
}

\section{下村芳樹** 木見田康治** 赤坂文弥*** \\ Yoshiki SHIMOMURA, Koji KIMITA and Fumiya AKASAKA}

Key words servicification, service engineering, service design, high value addition, product-service system

\section{1. は じめに}

戦前〜戦後を通じてわが国の経済成長を支え続けてきた 製造業であるが, 近年の原材料価格や国内人件費の高騰, 東アジアを中心とする新興国の台頭により, その持続の上 での岐路に立たされている。すなわち，今後もわが国の製 造業が持続可能な成長を遂げるためには, 従来とは異なる 新たな競争力の源泉が必要である。そしてその1つがサー ビスであることが多方面で指摘され始めており，これには 大きく 3 つの社会的背景が存在している.

第 1 は, 地球環境問題に対する関心の急速な高まりであ る. 現代社会において，人工物ライフサイクルの閉ループ 化や脱物質化の手法が必要とされていることは言うまでも なく, 求められるサービスを人工物ライフサイクル全体に おいて提供することにより, 脱物質的に受給者の要求を充 足することが期待されている.

第 2 は, 10 年以上にわたって続く構造不況, アジア新 興国との競争激化による製品の低価格化の結果，わが国の 産業構造に対する改革が不可避の事態となっていることで ある。すなわち, この文脈では, 生産現場の単純な海外移 転による低価格化を指向することに重きを置く, 従来の物

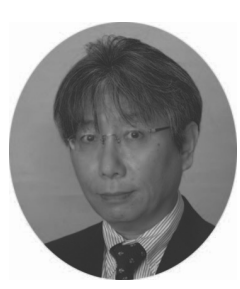

*原稿受付 平成 23 年 12 月 26 日

**正会員 首都大学東京大学院システムデザイ ン研究科（東京都日野市旭が丘 6-6）

***学生会員 首都大学東京大学院システムデザイ ン研究科（東京都日野市旭が丘 6-6）

下村芳樹

首都大学東京大学院システムデザイン研究科シ ステムデザイン専攻教授. 博士 (工学). 84 年 九州工業大学卒業. 2005 年より現職. 主とし て, サービス工学, 設計工学, ライフサイクル工学, メンテナンス工学等 の研究に従事.

木見田康治

2006 年東京都立大学工学部精密機械工学科卒業. 11 年首都大学東京システ ムデザイン研究科博士課程修了. 10 年より日本学術振興会特別研究員. 主 としてサービス工学, 設計工学の研究に従事. 11 年日本機械学会設計工 学・システム部門奨励業績表彰受賞.

赤坂文弥

2011 年首都大学東京大学院システムデザイン研究科博士前期課程修了. 同 年 4 月同研究科博士後期課程入学, 現在に至る。 2011 年より, 日本学術振 興会特別研究員 $(\mathrm{DCl})$. サービス工学, 製品・サービスシステムの設計に 関する研究に従事.
質・エネルギー集約型で生産中心型の産業構造・企業経営 でなく, 知識やサービスの提供により製品の付加価值を増 大するという，知識・サービス集約型で設計開発中心型の 産業構造・企業経営への変革が求められている.

第 3 は, サービス産業そのものの生産性向上に対する関 心の高まりである。運輸業における荷物仕分システムや, 小売業における顧客情報管理に代表されるように, 多くの サービスは, 物理的製品の利用によりその生産性の向上を 実現している，そのため，製造業における技術やノウハウ を用いてサービスの生産性を一層向上させることにより， サービス産業の活性化を図るのみならず，製造業製品の需 要の拡大へとつなげることが期待されている.

このような背景の下, 著者らはサービス工学の基礎を確 立することを目標とし, 現代社会におけるサービスの在り 方と, その設計方法を調査研究するための産学連携研究組 織として，2002 年 2 月にサービス工学研究会 ${ }^{1)}$ 設立し た. 同研究会はこれまでに, 2002 年 2 月〜 2005 年 3 月の 第 1 期, 2005 年 4 月〜 2008 年 7 月の第 2 期, 2008 年 10 月〜2011 年 9 月の第 3 期にわたる活動を行い, 2011 年 10 月からは新たに第 4 期の活動を開始している. 特に第 3 期 の活動においては, 産学の会員の混成によるワーキンググ ループを形成し，サービス設計の各段階を支援する具体的 手法の開発と, 同手法を実際のサービス事例に適用するこ とを行った。本稿では, サービス工学研究会におけるこれ らの取り組みを紹介することを通じて, サービス設計の各 段階を支援する工学的な実践手法を紹介する。

\section{2. サービスの設計プロセス}

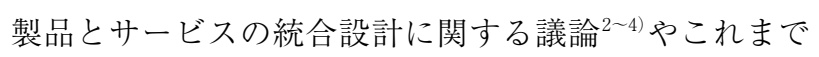
のサービス工学研究会における議論に基づけば, サービス の設計プロセスは,「要求分析」,「サービス概念設計」, 「サービス具体化設計」の 3 つの段階に大別することが可 能である．また，受給者の要求を真に充足可能であるよう なサービス設計を実現する上では，これらの3つの段階を 受給者視点に基づいて管理すること（「設計プロセス管 理」) が重要である（図 1). 


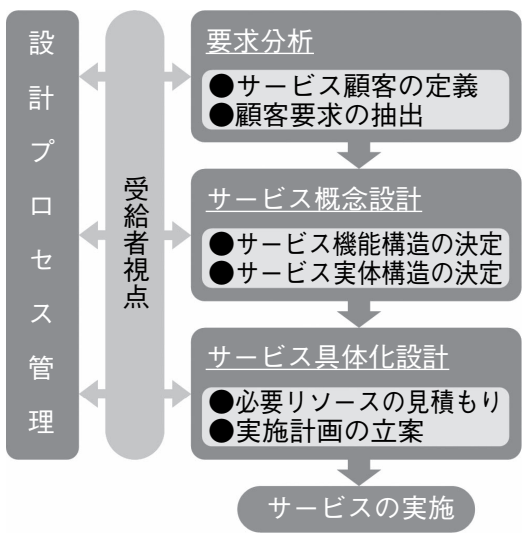

図 1 サービスの設計プロセス

要求分析とは, サービス設計における設計要件や制約条 件に関する情報を収集・整理する段階である，本段階で は，対象とする受給者のカテゴリを明確に規定することに より, 受給者像やその行動を明らかにし, サービスに対す る受給者の要求を適切に抽出する必要がある. 次にサービ スの概念設計とは, 要求分析により抽出した受給者の要求 を実現するサービスの機能構造を構築する段階である。こ の段階ではさらに, 設計解原理に相当する, サービス機能 を実現する人材・組織，製品等の実体を探索し，それらの 統合方法を検討する。サービスの具体化設計は, 製品設計 に扔ける「実体設計」や「詳細設計」に相当し, サービス のレイアウト，すなわちサービスに関わるステークホルダ の関係と各ステークホルダが準備，運用，保守を担当する 人材・組織，製品等の実体を決定する。本段階では，これ 以前の段階において構成した概念的な情報を，各ステーク ホルダが実際に保有するリソース等を考慮して実世界にお ける実体物との対応づけを行う。これにより，サービスの 実現構造を構成する実体の詳細を決定し, その準備, 運 用，保守に関する作業を定めたマニュアルやガイドライン を作成する

本サービス設計プロセスの最大の特徴は, 製品設計プロ セスと類似する 3 つの段階に加えて，それらに対する「設 計プロセスの管理」が，受給者視点に基づいて実施される 点にある。これまでのサービスに関する多くの研究におい て，サービスに扔ける価值は常にその受給者により決定さ れることが指摘されている5(5). つまり，サービス設計プ ロセスの各段階に扔ける過程とそのアウトプットは，常に 受給者の視点に基づく管理と評価にさらされることが重要 である。

以降では，本サービス設計プロセスの各段階において設 計者を支援する手法と，その適用事例について紹介する。

\section{3. 要求分析とサービス概念設計}

\section{1 要求分析テンプレート}

著者らは，受給者の要求を起点とした設計を可能とする ためのッールとして, 要求分析テンプレートを提案してい
る7). 要求分析テンプレートは, サービスに扔ける受給者 要求の表現・分析を目的とするッール群の総称であり, 「ペルソナテンプレート」,「性格・志向テンプレート」, 「脚本テンプレート」,「キーワードテンプレート」,「要求抽

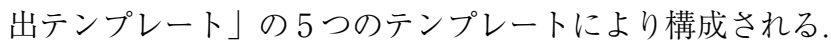

本テンプレートではまず，サービスが対象とする受給者 の情報をペルソナテンプレートを用いて記述する。ペルソ ナとは, 設計者の意思決定上の判断材料を得るために設定 される仮想的な受給者像8である。本テンプレートを用い て, 受給者の名前・性別・職業等の統計的デー夕の他, ラ イフスタイル等の心理的データを記述し, ペルソナを定義 する. 次に, 性格・志向テンプレートを用いて, ペルソナ テンプレートで定義したペルソナの性格・志向に関する情 報を拡張する。このペルソナおよびその性格・志向に関す る情報を基に，当該サービスに拈いて，ペルソナがある目 的・目標を達成するために取る行動に関するストーリーを 脚本テンプレートを用いて展開する。 このストーリーの中 には, サービスの設計過程において意思決定を行う際に, その判断材料となり得る情報を盛り达む必要がある。 キー ワードテンプレートでは, 脚本テンプレートで作成したス トーリーを基に, サービス提供の各場面（Phases of Service Encounter) と 4W1H (What, What like, How, Where, When）の 2 つの観点から, ペルソナの要求に関 倸するキーワードを整理する. 最後に, 要求抽出テンプレ 一トを用いて，キーワードテンプレートで整理された各キ ーワードに対して, ペルソナが要求する項目や品質を表す 要求項目/要求品質と, その評価尺度である品質要素を対 応付ける。

以上の手順により，サービスが対象とする受給者とその 要求を網羅的に把握するとともに, それらの要求が抽出さ れた根拠を明示化することが可能となる。

\subsection{Universal Abduction Studio}

Universal Abduction Studio（UAS）とは, 設計者との 動的なインタラクションにより, 設計課題の解決を支援す る協調的問題解決システムである ${ }^{9)}$. UAS は, ワークス ペース, 知識ベース群, 知識統合モジュール群により構成 される ${ }^{9)}$. 設計者は, 最初にワークスペースに設計上の課 題を配置し，その全体や部分に対して知識べースにある知 識を適用することにより設計を遂行する。また，この設計 遂行の際に, 知識統合モジュール群を用いた知識の統合 (異領域知識の利用による仮説の形成とその知識化) が行 われる。

UAS ではアナロジー推論 ${ }^{10)}$ 用いて知識統合を行う. アナロジーによる発想とは，ある分野（ターゲット領域） に打ける既存の知識を, その分野とは異なる別分野 (ベー 久分野）との類似性に基づき, ベース領域の要素を夕ーゲ ット領域に転写することにより，未知のアイデイアとして 獲得するものである ${ }^{10)}$. UAS では, インターネット上に 存在するWeb 情報を解析し, そこから得られる設計知識 を用いて知識べースを構築する方法が提案されている ${ }^{11}$. 


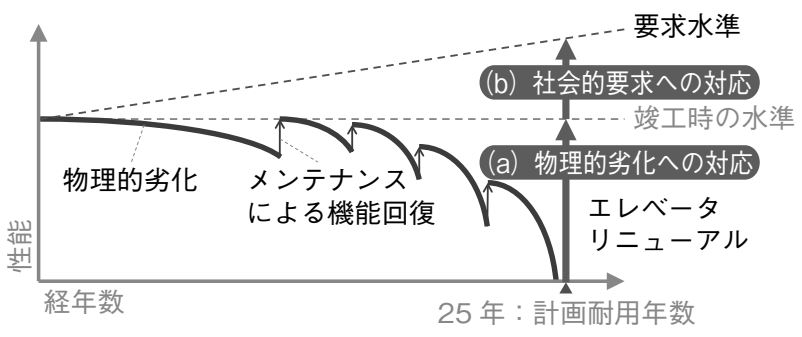

図 2 エレベータリニューアルサービス

Web 情報に基づく設計知識は, その内容の多様性や最新 性を確保することが容易であり，かつまた，大量の知識を 少ない労力で取得することが可能であることから，近年そ の基礎研究が積極的に行われており，この特徴はUAS の 知識ベースとしても適している。

本手法では，Web 情報源として例えば，サービス設計 に利用可能な記述が数多く存在し, かつ一定の信頼性が確 保可能な「日経プレスリリース ${ }^{12)} 」 の$ 記事（PR 記事）を 採用し，これにWebクローラの手法を適用することによ り PR 記事を取得している。そして, Webより多量に取 得した PR 記事から, 設計中のサービスが対象とする受給 者の要求に対して類似性の高い語彙を含む $\mathrm{PR}$ 記事を抽出 し，これを設計者に提示することで, 設計者が受給者要求 を実現するサービスの機能を導出することを支援する．

本手法は，前述のサービス設計プロセスにおいて，設計 者が要求分析段階で抽出された受給者要求に基づき，概念 設計段階においてそれらの要求を実現する機能構造を構築 する活動を支援する手法として位置づけられる。

\section{3 エレベータリニューアルサービスへの適用例}

ここでは要求分析テンプレートならびに Web 情報を用 いたUASによる設計支援手法を，冒頭に述べたサービス 工学研究会第 3 期活動に扔いて, エレベータリニューアル サービスに対して適用した事例を紹介する。本適用事例で は，サービス開発の実務者が UAS を用いて新たなサービ 又機能を導出可能であるか否かを確認することを通じて, 主としてサービス設計におけるUAS の有用性を検証した。

エレベータリニューアルとは，エレベータの安全性，信 頼性等の向上を目的とした機能改善である。エレベータリ ニューアルにおいてこれらの機能改善が必要となる主たる 理由には，以下の 2 つがある，1つは，エレベータの物理 的劣化に対する対応の必要性である（図 2 (a))。図 2 に 示すように，使用の初期段階におけるエレベー夕の物理的 な劣化は，部品交換を実施する等，メンテナンスにより当 該機能を回復することが比較的容易である。しかしなが ら，長期にわたる使用年数の経過に伴い，エレベータには 経年劣化が発生し，必要とされるメンテナンスの頻度が増 加する，一方，提供者側では，長期間にわたって同一機種 の部品在庫を確保し，供給体制を維持することは容易では ない，そのため,メンテナンスによる機能回復には自ずと 限界が生じることになる。もう 1 つの理由は, 社会的な要

\begin{tabular}{|c|c|c|c|}
\hline \multicolumn{2}{|c|}{ 名前: 田中 徹 } & \multirow[t]{4}{*}{ 画像: } & \multirow{4}{*}{$\begin{array}{l}\text { マンション環境: } \\
\text { エレベータは1基 } \\
\text { 分譲マンション(築27年) } \\
\text { 鉄筋コンクリート造 } \\
\text { オートロック } \\
\text { 10階建 } \\
\text { 家族で住んでいる方が多い }\end{array}$} \\
\hline 年齢: 50 & 性別: 男 & & \\
\hline \multicolumn{2}{|c|}{ 家族: 妻、娘、息子の 4 人家族 } & & \\
\hline \multicolumn{2}{|c|}{ 一言:熱血親父 } & & \\
\hline \multirow{2}{*}{\multicolumn{2}{|c|}{$\begin{array}{l}\text { ショート脚本: } \\
\text { 今度、エレベータリニューアル } \\
\text { に関する理事会がある。古い } \\
\text { エレベータナジ感じていたから } \\
\text { 確かに妥当だろう。保守会社 } \\
\text { の提案内容次第だが、住民 } \\
\text { 全員が納得いく内容でリ } \\
\text { ニューアルしてもらいいな。 }\end{array}$}} & $\begin{array}{l}\text { 個性: } \\
\text { 社交的 } \\
\text { マイペース } \\
\text { 地味にあつい } \\
\text { 頑固 }\end{array}$ & $\begin{array}{l}\text { 地域環境: } \\
\text { マンショ周囲は物静か } \\
\text { ベッドタウン } \\
\text { 商店街が近くにある }\end{array}$ \\
\hline & & \multirow{2}{*}{$\begin{array}{l}\text { ライフスタイル: } \\
\text { 東京都江東区 } \\
\text { マンション5階在住 } \\
\text { 平日は21時ごに帰宅 } \\
\text { 基本的には土日は休み }\end{array}$} & $\begin{array}{l}\text { メモ: } \\
\text { 部屋が5階にあるため、いつ }\end{array}$ \\
\hline \multicolumn{2}{|c|}{$\begin{array}{l}\text { キャリア: } \\
\text { 関西圏の私立大学卒業 } \\
\text { 建設会社に勤務 }\end{array}$} & & $\begin{array}{l}\text { 理事会には常に参加 } \\
\text { マンション住民のーダー格 } \\
\text { みんなの意見に耳を傾ける }\end{array}$ \\
\hline
\end{tabular}

図 3 ペルソナテンプレートへの記入例

求の変化に対する追従が必要であるという点にある（図 2 (b)). 時代の変遷とともに厳しさを増す, 法律によって 定められる安全基準を遵守し, 福祉や防犯等に関する新た な社会的要求に追従するためには, 多くの場合, エレベー タリニューアルによる機能改善が不可避である.

しかしその一方で，マンションに代表される集合住宅の 住民に対してリニューアルを促進する際の訴求点は, 現状 の多くの場合，エレベー夕自体，すなわち，物理的製品に おける新機能が中心となっている, そのため, 設備老朽化 に伴って必要なリニューアルを実施するための訴求点が実 現場では不十分であることが懸念されており，物理的製品 の性能や機能に頼るだけでなく, 行為的製品も併せたサー ビス新機能を提案し，リニューアルに対する十分な訴求点 を確保とすることが強く望まれている。

本適用事例では, 集合住宅の住民をエレベータリニュー アルサービスの受給者とし, 要求分析テンプレートを用い て要求分析を行った，本分析では，まず，ペルソナテンプ レートを用いて受給者像の記述を行った。図 3 にペルソ ナテンプレートの適用結果の例を示す。

図 3 に示す結果には，住民の名前や性別，職業等の統計 的デー夕に加え, マンション環境や地域環境等のエレベー タリニューアルサービスに関わる情報が記述されている. 次に，各ペルソナに対してその性格・志向に関する情報を 加え, これらの情報を基に, 脚本テンプレートの記述を行 った，図４に示すように，本分析では，エレベー夕の利 用場面だけでなく，マンションの理事会等，サービスに関 わる全ての場面に対して, ペルソナが取る行動の記述を行 った。そして，各場面に扔いてペルソナが取る行動 (Action) を，図 5 に示すように，キーワードテンプレー 卜を用いて $4 \mathrm{~W} 1 \mathrm{H}$ の観点から分解することにより，ペル ソナの要求に関わるキーワードを整理した. 最後に, 各キ ーワードから連想される住民の要求項目あるいは要求品質 を抽出し，その評価尺度である品質要素を決定した。图 6 にその一部を示す。これらの分析結果に対して，エレベータ リニューアルサービスの実務者による評価を実施した結果, 抽出された要求に対して一定の妥当性と網羅性を確認した。

次に, 要求分析段階において抽出されたエレベータリニ 


\section{【理事会開催前】}

ほう、エレベータリニューアルに関する理事会があるのか。古いエレベータだと感じて いたから確かに妥当だろうな。保守会社の提案内容次第だが、住民全員が納得いく 内容でリニューアルできたらな。しかし、ただでさえもめて決めた今の積立金でまか なえるのだろうか。

図 4 脚本テンプレートへの記入例

\begin{tabular}{|c|c|c|c|c|c|c|c|}
\hline $\begin{array}{l}\text { Phases of } \\
\text { Service } \\
\text { Encounter }\end{array}$ & Action & Whom & What & When & Where & Why & How \\
\hline \multirow{3}{*}{$\begin{array}{l}\text { 理事会 } \\
\text { 開倠解 }\end{array}$} & （知る） & & $\begin{array}{l}\text { 理事会が開催 } \\
\text { されること }\end{array}$ & & （自宅） & & \\
\hline & (願う) & 住民全員 & $\begin{array}{l}\text { リニューアルに } \\
\text { 納得すること }\end{array}$ & & （自宅） & $\begin{array}{l}\text { エレベータ } \\
\text { が古いためめ }\end{array}$ & \\
\hline & (不安に思う) & & 積立金 & & （自宅） & & \\
\hline
\end{tabular}

図 5 ペルソナの要求キーワードの例

\begin{tabular}{|c|c|c|}
\hline キーワート゚ & 要求項目／要求品質 & 品貿要素 \\
\hline $\begin{array}{l}\text { エレベータリニューアル } \\
\text { に関する理事会 }\end{array}$ & 理事会が計画的に行われてほしい & 処理迅速性、処理確実さ \\
\hline $\begin{array}{l}\text { エレベータが古いと } \\
\text { 感じる }\end{array}$ & 安心してエレベータに乗りたい & 危険保護性、危険防止性 \\
\hline 全員が納得のいく内容 & $\begin{array}{l}\text { 住民全員が納得するリニューアルであっ } \\
\text { てほしい }\end{array}$ & 好都合度、手ごろ感、負担軽さ \\
\hline 今の積立金 & $\begin{array}{l}\text { 今までの積立金でリニューアルを行って } \\
\text { ほしい }\end{array}$ & 手間代行性、負担軽さ \\
\hline 発表される & $\begin{array}{l}\text { リニューアルの提案がわかりやすくあっ } \\
\text { てほしい }\end{array}$ & 対応確実さ、わかりやすさ \\
\hline $\begin{array}{l}\text { 今のエレベータが法規 } \\
\text { に合っていないこと }\end{array}$ & 法規に合ったエレベータであってほしい & $\begin{array}{l}\text { 危険保護性、危険防止性、 } \\
\text { 信用性 }\end{array}$ \\
\hline
\end{tabular}

図6 抽出された要求品質と品質要素の例
ユーアルサービスに対する住民の要求に対して，UAS の 知識ベースにあらかじめ蓄積された $\mathrm{PR}$ 記事から, 各要求 に対して類似性の高い語彙を含む記事を抽出した，本事例 適用では, 知識ベースとして用いる $\mathrm{PR}$ 記事を, 最新の 「日経プレスリリース」における, IT, 流通, 金融, メー カ, サービス, 建設の各業界関連記事から 200 件, 合計 1200 件の記事の取得を行い, データベースに蓄積した. この抽出された $\mathrm{PR}$ 記事を，エレベータ新機能開発に携わ る実務者に提示することにより，新機能の導出を行った． 本適用事例では, UAS を用いて住民の要求と, PR 記事中 の語彙との類似性に関するスコアを算出し, 高スコアを得 た上位 100 件の PR 記事を提示した。これらの提示された 記事を参考に，エレベー夕新機能開発に携わる実務者が導 出した新たな機能の例を表 1 に示す。また, 図 7 は, 表 1 に扔ける機能の導出過程を示した例である。図 7 の例で は,「リニューアルの提案内容がわかりやすくあってほし い」という要求に対して,「住宅メーカのWebサイト」 に関する PR 記事が抽出されている。本 PR 記事では, 顧 客が希望する間取りを 3 次元で仮想的に体験できるWeb サイトが紹介されていた，実務者はこの記事を基に，住民 が希望するエレベータ内のインテリアに関する 3 次元の仮 想的な体験を与えることにより, 提案するエレベー夕製品 に対する受給者のより適切な理解を促すという新機能を導 出している.

表 1 導出された機能の例

\begin{tabular}{|c|c|}
\hline 導出機能 & 機能の概要 \\
\hline 三次元バーチャル体験を可能にする & $\begin{array}{l}\text { リニューアル後のエレベータを顧客に事前にバーチャル体験してもらうことにより, 提案内容や提供 } \\
\text { サービスを理解してもらう }\end{array}$ \\
\hline 壁を張替え可能にする & $\begin{array}{l}\text { エレベータのカゴの壁に張替え可能なフィルムを設置することにより, コーディネートを楽しめるよ } \\
\text { うにする }\end{array}$ \\
\hline 薄型モニターを設置する & 薄型モニターを壁に設置し四季の風景等を映すことで気分転換してもらう \\
\hline 観光情報を配信する & ガイドに掲載されている観光地の紹介や旅行者の写真などを映像として配信する \\
\hline $\begin{array}{l}\text { リニューアルの事例集・質問集を用意 } \\
\text { する }\end{array}$ & $\begin{array}{l}\text { リニューアルに関する Q \& A や事例集, エレベータ制御に関する問題集を用意することにより，リニ } \\
\text { ユーアル相談を円滑化する }\end{array}$ \\
\hline WIMAX を装備，WI-Hi を提供する & $\begin{array}{l}\text { エレベータに WIMAX を装備し，WI-Hi を提供可能とすることにより，エレベータ内で障害者へコミ } \\
\text { ユニケーション可能とする }\end{array}$ \\
\hline 太陽熱とガスで電気，熱を & $\begin{array}{l}\text { 太陽熱やガスコージェネレーションを活用し電気・熱を供給することにより, 電力不足時に対応可能 } \\
\text { とする }\end{array}$ \\
\hline デマンド制御を行う & デマンド制御を可能とし, 省エネの達成や環境意識の向上につなげる \\
\hline 起動回数, 電力を表示する & 起動回数, 電力を利用者に表示することにより, 省エネルギー化を促進する \\
\hline 人物認識を行う & $\begin{array}{l}\text { セキュリティカード等での人物認識により, 老人, 幼稚園児等のエレベータ乗車時のビデオクリップ } \\
\text { を子供や親に自動配信する }\end{array}$ \\
\hline 運行状況をWeb で表示する & $\begin{array}{l}\text { エレベータの起動回数, 消費電力, 乗降階, 時間別乗車回数, 防犯カメラ映像を Web 配信し, 運行 } \\
\text { 状況を把握できるようにする }\end{array}$ \\
\hline 電気自動車のバッテリーを活用する & $\begin{array}{l}\text { 電気自動車のバッテリーを活用し, 計画停電実行時にエレベータ内部に人が閉じ込められないように } \\
\text { する }\end{array}$ \\
\hline $\begin{array}{l}\text { エレベータに関する特許やスコアを表 } \\
\text { 示する }\end{array}$ & $\begin{array}{l}\text { エレベータの制御や機能に関する最新特許 PR や各社のスコアを表示することによりリニューアルの } \\
\text { 内容を理解してもらうう }\end{array}$ \\
\hline $\begin{array}{l}\text { FELICA による顧客認識, 呼び自動 } \\
\text { 登録機能を搭載する }\end{array}$ & 顧客認識，呼び自動登録機能をエレベータに搭載し安全性を高める \\
\hline ペットがいることを判別する & 他の利用者がエレベータ内にペットがいることを判別可能とすることにより，ペットの安全を確保する \\
\hline ネットスーパーの広告配信をする & $\begin{array}{l}\text { ネットスーパーの新規加入 PR 等をエレベータのモニターに配信し, 申込の URL を QR コードから取 } \\
\text { 得可能にする }\end{array}$ \\
\hline スタンバイモードを搭載する & $\begin{array}{l}\text { 内部の照明をドアが開いたとき消灯するなど, エレベータにスタンバイモードを搭載することにより } \\
\text { 省エネを図る }\end{array}$ \\
\hline 昇降路壁を活用した耐震対策を行う & 昇降路のスペースを活用して昇降路壁を強化することにより，建築建物の耐震対策を行う \\
\hline
\end{tabular}




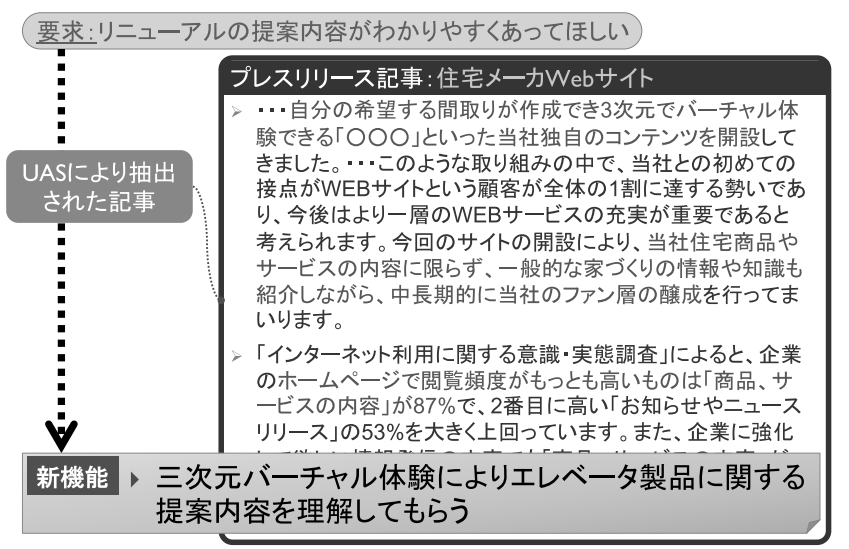

図 7 機能の導出過程の例

本事例において実務者により導出された機能は, エレベ 一夕，すなわち，物理的製品の新機能だけでなく，エレベ 一夕に付随して提供される行為的製品に関する新機能も含 まれている，このように，物理的製品だけでなく行為的製 品に関するサービス新機能が導出された要因としては, UASにより提示されたPR 記事の内容が大きく寄与して いると考えられる。本適用事例において新機能導出を促し た PR 記事は，提示した 100 件中 27 件に上った。 また， これらの業界別の内訳は，IT が 8 件，流通が 4 件，サー ビスが 2 件, メーカが 3 件, 金融が 1 件, 建設・住宅が 9 件であった。すなわち，抽出された受給者要求を起点とし て, 複数の業界から広範なサービス機能に関する情報を収 集したことがサービス新機能導出の支援につながったと考 えられる，以上のことから UAS は，概念設計における機 能構造の構築に対して一定の支援を行うことが可能である といえる.

\section{4. サービスの具体化設計}

\section{1 リソースの最適配分によるサービス改善設計支援}

図 8 はサービスの改善設計におけるリソース投入と受 給者満足向上の関係を表すモデルである。このモデルで は, 受給者の満足を受給者要求の充足, サービス改善案の 実現，リソースの投入という 3 つの段階を経て実現するこ とを表している。リソースの投入によりサービス改善案が 実現され, それにより受給者要求が充足され, 受給者満足 が向上するという段階的な充足関係を表現している。本章 で紹介する手法は，この構造を前提として，「有限リソー ス下において, 複数のサービス改善案のうち, どの改善案 に多くのリソースを投入すれば受給者満足を最大に向上で きるのか」という最適化問題を解くことにより，集中的か つ優先的に実施すべき改善案を特定するものである。ただ し，ここでいうリソースはサービス改善の全ての活動にお いて消費されるプリミティブなリソースである金銭リソー スと時間リソースのみを対象とする.

本手法では, サービスマーケティング分野で顧客要求を 分析・表現するために用いられてきた Means-End

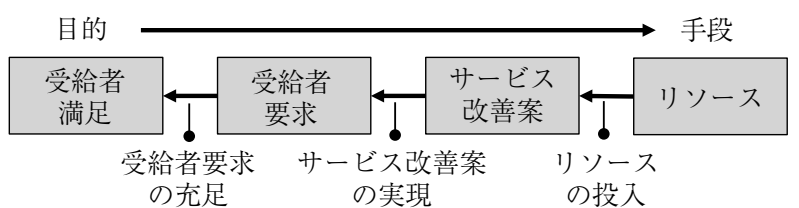

図 8 サービスの改善モデル

Chain ${ }^{13)}$ の考え方に基づき, サービスに対する受給者要求 を，目標，要求項目，サービス品質要素の 3 つの階層によ りモデル化する。ただしここで，目標は「受給者のサービ ス受給における目的」, 要求項目は「受給者が行いたいこ と, ニーズ」, サービス品質要素は「サービスの品質を評 価する尺度となり得る要素」として定義する。 そして, 上 記 3 要素と受給者満足の計 4 要素をノードとし, それらの関 係をアークとしたグラフ構造を構築し，ノードの值とアーク の重みの線形加重和により，受給者満足の值を算出する ${ }^{14)}$.

一方, サービスの改善により受給者満足の向上を実現す るためには，サービス提供者のリソースを投入することで サービス改善を実施し，受給者要求を充足することが必要 であるが，一般に改善案の実施におけるリソース投入の効 果はリソースの種類および改善案の種類によりさまざまで ある。そこで本手法では, 改善案の実現度合いとリソース 投入量の多様な関係性をシグモイド曲線により表現する. シグモイド曲線は，中央值と中央值における傾きにより， 2 変数間の多様な関係性を記述する手段であり，ここで は，中央值により立ち上がりの早さを表現し，また傾きは 伸び率を表現する.

本手法では, 以上のモデルを用いて, 受給者満足の值を 最大化する最適なリソース配分を算出する。 この最適化計 算には，遺伝的アルゴリズムを用いる。すなわち本最適化 では，遺伝子をリソースの配分比率とし，各遺伝子には 0 から 1 の值を設定する。また，適合度を受給者満足の值と する。この最適化により，受給者満足を最大化する最適な リソース配分量を算出し，この結果を設計者に提示する.

このように本手法は, 概念設計段階で得られた複数の改 善案 (設計解) に対して, 受給者満足を最大化する最適な リソース配分量を算出することで，優先的かつ集中的に実 践すべきサービスの改善案を特定することを可能とする. すなわち本手法は，概念的な設計解という入力に対して， 実世界における制約条件（提供時に投入可能なリソース） を考慮しながら，各設計解採用の優先度というサービスの 提供準備時に対して重要となる情報を提示するものであ り, サービスの具体化設計における設計者支援手法と位置 付けられる。

\section{2 電設工事サービスへの適用例}

サービス工学研究会第 3 期活動において, 4.1 節に述べ たサービス改善設計支援手法を, 電力設備の工事・保全サ ービス（電設工事サービス）に適用した。本サービスにお いて，サービス提供者である工事会社は，受給者である電 力会社が所有する発電・変電・送電設備を対象に点検, 修 


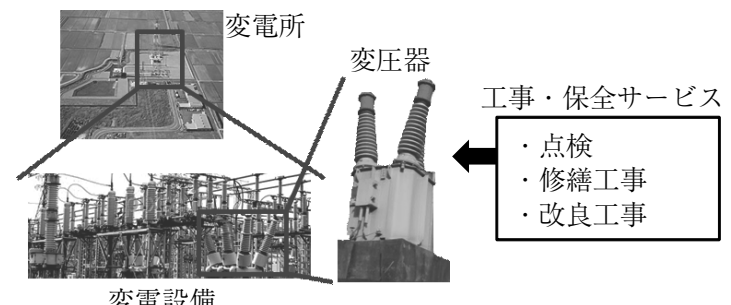

図 9 電設工事サービス

表 2 サービスの改善案

\begin{tabular}{|c|c|c|c|c|c|}
\hline & \multirow{2}{*}{ サービス改善案 } & \multicolumn{2}{|c|}{ 金銭 } & \multicolumn{2}{|c|}{ 時間 } \\
\hline & & 中央值 & 傾き & 中央値 & 傾き \\
\hline 1 & IC チップによる入出庫管理 & 0.6 & 8 & 0.2 & 9 \\
\hline 2 & 協力会社との IT 連携 & 0.9 & 1 & 0.8 & 1 \\
\hline 3 & ヒヤリハット集の充実 & 0.1 & 10 & 0.6 & 1 \\
\hline 4 & 工程 · 工法の知識集約化 & 0.3 & 9 & 0.5 & 1 \\
\hline 5 & 個人のスキル評価 · 管理 & 0.2 & 9 & 0.7 & 1 \\
\hline 6 & $\begin{array}{l}\text { 過去工事における原価・要員数 } \\
\text { 情報の蓄積 }\end{array}$ & 0.3 & 9 & 0.4 & 1 \\
\hline 7 & 部品状態 DB の構築 & 0.7 & 1 & 0.5 & 1 \\
\hline 8 & 緊急時における体制作り & 0.2 & 9 & 0.2 & 9 \\
\hline
\end{tabular}

繕工事，および改良工事を実施する（図 9). 近年, 国内 の多くの発電・変電・送電設備の一斉老朽化に伴い, サー ビス提供者である電設工事会社に対してより効果的で迅速 な設備保全を行う能力が強く求められるなど, 工事会社を 取り巻く環境や受給者要求が大きく変化している。 そのた め, 対象とした電設工事サービスの現場では, 現状のサー ビスを改善し，新たなサービスを構築することの必要性が 強く主張されている.

本事例ではまず, サービスの受給者である電力会社の電 設工事サービスに対する要求の構造をモデル化した。ここ での要求抽出・モデル化には, 3.1 節で述べた要求分析テ ンプレート7)を用いた。加えて, 事例関係者へのアンケー 卜調査により，各ノードをつなぐアークの重みを算出した.

次に, サービス現場への実地調査とヒアリング調査を通 じて, 現場の責任者および経営者が考えているサービス改 善案を抽出した。その結果, 表 2 の最左部に示す計 8 種 のサービス改善案を抽出した上で, 各改善案に関して, 改 善案の実現とリソース投入量の関係を，シグモイド関数を 用いてモデル化した。 その結果を表 2 に示す。

以上の結果をもとに，各改善案に対するリソース配分の 最適化を実施した。本事例では，改善に投入する金銭・時 間リソースの総量を 1 とした場合と，3とした場合のそれ ぞれにおいて最適化を行った。ここで，前者は比較的小規 模かつ短期的なサービス改善を, 後者は比較的大規模もし くは長期的な改善を意味する。最適化計算の結果, 図 10 および図 11 に示すリソース配分結果が導出された。投入 可能なリソース量を 1 とした場合には, 「工程・工法の知 識集約化」「緊急時における体制作り」といった改善案に 対して多くのリソースが配分された（図 10). 他方, 投入 可能なリソース量を 3 とした場合は, 上記の 2 つの改善案

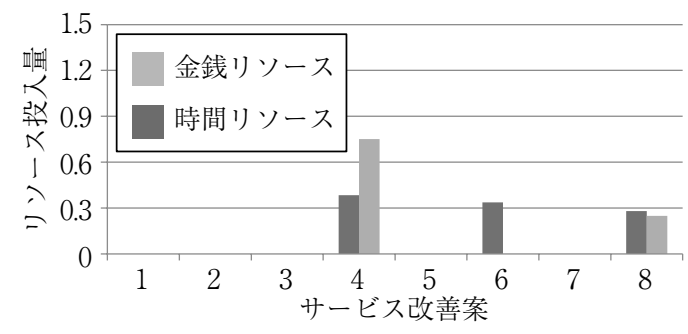

図 10 リソース配分案（リソース量 $=1.0 ）$

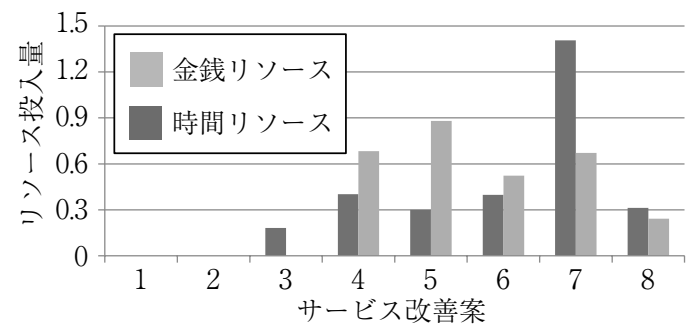

図11 リソース配分案（リソース量 $=3.0 ）$

に加えて, 「部品状態の DB の構築」,「個人スキル評価 · 管理」,「過去工事における原価・要員数情報の蓄積」とい った改善案に対して多くのリソースが配分された（図 11）.

本事例では，このリソース配分量を各改善案の優先度と 見なすことにより, 小規模および大規模な改善の双方にお いて，サービスの実施時においてどの改善案に対して注力 すべきかという情報を設計者に提示し，これによりサービ スの実施準備段階における意思決定が支援可能であった。

\section{5.おわりに}

本稿では, サービス設計プロセスにおける各段階を支援 する手法を紹介するとともに，それらをサービス工学研究 会という産学連携研究組織の活動を通じて, サービス事例 に適用した取り組みを紹介した。これらの手法では，製品 設計分野における手法とマーケティング分野等において広 く用いられている受給者の表現・分析手法を組み合わせる ことにより，サービス設計プロセスの各段階における過程 とアウトプットを, 受給者の視点に基づき管理し, 評価す ることを可能としている。しかしながら，これら従来手法 の組み合わせによる解決が困難であるサービス固有の問題 として，以下の 2 つが挙げられる。

1 つは, サービス品質の不確実性である。サービスの品 質は，サービスを構成する実体の属性（例えば，従業員の 業務遂行能力など）に大きく影響される。しかしながら， 従業員の疲労に伴いその業務遂行能力が低下するように, サービスを構成する実体の属性は, サービスの提供状況に よって容易にばらつく。この傾向はサービスがその構造に 多くの人的要素を含むことから，一般的な物理製品に比べ てより顕著である。すなわち，サービスの品質を高め，そ れを安定的に提供するためには, サービスの品質に影響を 与える実体の属性を適切かつ効率的に把握し, 設計段階に 
おいて適切な対策を講じる必要がある。

残るもう 1 つは, 実体の多様性による投入リソースの増 大に関する問題である。受給者の要求を実現するサービス の機能は, 物理的な製品から人材や組織に至るまで, 多様 な実体により発現される。一般的に，単一のステークホル ダにより，これらの実体の準備，運用，保守を行う場合， 莫大なリソースを投じる必要がある。そのため，実体の準 備，運用，保守に投じるリソースを最小化し，かつまた， その投入により得られる利益を最大化するためには, 複数 のステークホルダによる協業的なサービス実現構造を構築 する必要がある。

前者に対しては, 著者らはすでに, サービス品質の不確 実性を高める要因を設計段階において抽出する手法 ${ }^{15)}$ と, それらの要因によるサービス品質の変動を可視化するシミ ユレーション手法 ${ }^{16)}$ の開発に着手している。 また，後者に 対しては，サービスに介在する複数のステークホルダに関 して，各ステークホルダの要求充足度と投入リソース量等 を表現，評価するためのフレームワーク ${ }^{17)}$ を提案している.

今後は，これらの手法をサービス事例に対して適用する ことで，その有用性を検証とするとともに，よりサービス 固有の問題に特化した設計支援を実現することを目指す，

\section{参 考 文 献}

1）サービス工学研究会 HP: http://www.service-eng.org/

2) A. Tukker and U. Tischner: New Business for Old Europe, Greenleaf Publishing, (2006).

3) H. Meier, R. Roy and G. Seliger: Industrial Product-ServiceSystems-IPS2 Providing, Annals of the CIRP, 59, 2 (2010) 607.

4) J.C. Aurich, C. Fuchs and M.F. DeVries: An Approach to Life Cycle Oriented Technical Service Design, Annals of the CIRP, 53,
1 (2004) 151.

5) S.L. Vargo and R.F. Lusch : Evolving to a New Dominant Logic for Marketing, Journal of Marketing, 68, 1 (2004) 1.

6) C. Grönroos : Service Management and Marketing : A Customer Relationship Management Approach, John Wiley \& Sons, (2000).

7）サービス工学研究コンソーシアム：2007 年度サービス産業生産 性向上支援調查事業 (サービス工学研究開発分野) 報告書一顧 客満足度抢よび生産性向上に向けたサービス表現/評価の工学的 方法論一, (2008).

8) A. Cooper:The Inmates Are Running the Asylum, SAMS/ Macmillan, (1999).

9）下村芳樹, 吉岡真治, 武田英明, 冨山哲男：アブダクションに 基づく設計者支援環境の基本構想, 日本機械学会論文集 $\mathrm{C}$ 編, 72, 713 (2006) 274.

10) S. Bhatta, A. Goel and S. Prabhakar: Innovation in Analogical design-A Model-based Approach, Artifical Intelegence in Design, (1994) 57.

11）北井康幸, 沖和弘, 千葉龍介, 下村芳樹：サービス設計のため の設計知識データベースの構築, 日本機械学会第 20 回設計工 学・システム部門講演会講演論文集, （2010） 492.

12）日本経済新聞-NIKKEI NET : http://releases.nikkei.co.jp/

13) J. Gutman: A means-end Chain Model Based on Consumer Categorization Processes, Journal of Marketing, 46, 1 (1982) 60.

14) F. Akasaka, R. Chiba and Y. Shimomura: An Engineering Method to Support Customer-Oriented Service Improvement, Proceedings of the 3rd CIRP IPS ${ }^{2}$ Conference, (2011) 87.

15）太田航介, 御子柴怜志, 木見田康治, 舘山武史, 下村芳樹：サ ービス設計のための不確実性分析手法, 日本機械学会第 21 回設 計工学・システム部門講演会講演論文集，（2011） 97.

16）御子柴怜志, 木見田康治, 舘山武史, 下村芳樹：顧客行動に起 因するサービス故障を考慮したサービスプロセスシミュレータ， 2011 年度精密工学会秋季大会学術講演会講演論文集，(2011） 83.

17）渡辺健太郎，太田航介, 御子柴怜志, 舘山武史, 下村芳樹：統 合サービス評価フレームワークに基づくサービス評価, Design シンポジウム 2010 講演論文集，（2010）。 